\begin{tabular}{l|l|l|l|l}
\hline Epoch & PA. & Dist. & Magn. & Wt. \\
\hline
\end{tabular}

$\theta$ Gruis. Jacob $23^{8}$. St. 12013

RA. $23^{\mathrm{h}} 1^{\mathrm{m}} \mathrm{I}^{\mathrm{s}}$ Decl. $-44^{\circ} 4^{\prime}$.

\begin{tabular}{r|c|c|cc|c}
1895.824 & 28.9 & 2.25 & 5 & 8 & 5 \\
841 & 28.7 & 1.84 & 5 &, 7.5 & 4 \\
846 & 28.2 & 1.94 & 5 & 8 & 5 \\
\hline 1895.837 & 28.6 & 2.02 & 5 &, 7.8 &
\end{tabular}

Cord. ZC. $23^{\text {h }} 712$ >dpl.c. St. 12192.

RA. $23^{\mathrm{h}} 27^{\mathrm{m}} 52^{\mathrm{s}}$ Decl. $-57^{\circ} 35^{\prime}$.

\begin{tabular}{r|c|c|c|c|c}
$1895.87 \mathrm{I}$ & 206.8 & 1.96 & $7.5,8$ & 6 \\
936 & 208.2 & 1.94 & $7.8,8.8$ & 6 \\
$96 \mathrm{I}$ & 207.5 & 1.93 & $7.5,8.5$ & 4 \\
\hline 1895.918 & 207.5 & 1.95 & $7.6,8.4$ &
\end{tabular}

Sydney Observatory 1896 Febr. 21.

\begin{tabular}{l|l|l|l|l}
\hline Epoch & PA. & Dist. & Magn. & Wt. \\
\hline
\end{tabular}

Innes 25 . Cord. GC. 3 1907.

RA. $23^{\mathrm{h}} 29^{\mathrm{m}} 47^{\mathrm{s}}$ Decl. $-5^{8^{\circ}} 3^{\mathrm{\prime}}$.

\begin{tabular}{r|r|r|rr|r}
1895.871 & 238.5 & 1.14 & $7.5,7.8$ & 6 \\
936 & 236.9 & 1.16 & $7.3,7.8$ & 5 \\
961 & 235.4 & 1.28 & $7,7.5$ & 4 \\
\hline 1895.917 & 237.1 & 1.18 & $7.3,7.7$ &
\end{tabular}

Sellors 14. St. 12307.

RA. $23^{\mathrm{h}} 45^{\mathrm{m}} 17^{\mathrm{s}}$ Decl. $-5^{\circ} 16^{\prime}$.

\begin{tabular}{r|c|r|c|c|c}
1895.871 & 65.9 & 1.27 & $7.3,7.3$ & 7 \\
994 & 62.6 & 1.28 & 7,7 & 8 \\
\hline 1895.937 & 64.1 & 1.28 & $7.2,7.2$ & \\
& & \multicolumn{3}{|c}{ H. C. Russell. }
\end{tabular}

Note on the orbit of Sirius.

In the Astr. Nachr. No. 3336 Dr. Zwiers gives a very elegant method of determining the orbit of a double star, illustrating his formulae by the orbital movement of Sirius.

In instancing previous orbits he makes no reference to one I determined some time ago, mainly with this object in view, to demonstrate that a definitive determination of the orbit of Sirius was, at present, an impossibility.

I do not call attention to this, however, as a protest against $Z$ wiers' orbit, but the rather to call attention to the close agreement between Zwiers' orbit and my own, an agreement that would no doubt have been referred to had it been known.

The following are the two orbits:

Lovedale, South Africa, 1896 April I.

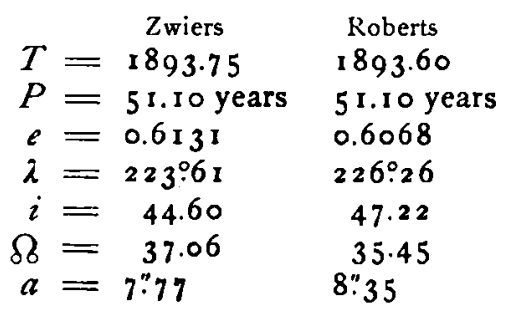

The agreement, I think, is very remarkable, and cannot be the result of mere chance. The paper, in which my determination is made, is in the Astr. Journal No. 328.

I have another determination ready - one in which account is taken of the weight of the several observations but I am waiting for the appearance of the companion.

Alex. W. Roberts.

\title{
Zur Reduction wegen Krümmung des Parallels beim Meridiankreis.
}

Zur Reduction der am Meridiankreis gemachten Ab. lesung wegen Krümmung des Parallels geben Brünnow und Chauvenet und wohl auch die anderen Lehrbücher über praktische Astronomie die Formel

$$
1 / 2 \sin 2 \delta \cdot \frac{2 \sin ^{2} 1 / 2 t}{\sin \mathrm{I}^{\prime \prime}}+\sin 2 \delta \cdot \sin ^{2} \delta \frac{2 \sin 41 / 2 t}{\sin \mathrm{I}^{\prime \prime}} .
$$

Bei Chauvenet ist für $\delta$ geschrieben $\delta^{\prime}$, welches die aus der Kreisablesung hervorgehende Declination bedeutet, die von der wahren um den Betrag des Reductionsausdrucks abweicht; doch ist hinzugefügt, dass man statt $\delta^{\prime}$ auch die wahre Declination $\delta$ zur Berechnung des Reductionsausdrucks benutzen könne. Bei Brünnow ist überhaupt nicht besonders erwähnt, dass eigentlich die unreducirte Declination $\delta^{\prime}$ zur Verwendung zu kommen hätte.

Man wird nun wohl kaum jemals die unreducirte Declination $\delta^{\prime}$ bei der Berechnung der Reduction zur Verwendung bringen wollen, sondern immer die entweder genau oder mindestens in hinlänglicher Näherung bekannte wahre Declination $\delta$.

Aus der Gleichung $\operatorname{tg} \delta=\operatorname{tg} \delta^{\prime} \cos t$ ergiebt sich jedoch die Reduction $\delta^{\prime}-\delta$, durch $\delta$ ausgedrückt, gleich

$$
1 / 2 \sin 2 \delta \cdot \frac{2 \sin ^{2} 1 / 2 t}{\sin I^{\prime \prime}}+\sin 2 \delta \cdot \cos ^{2} \delta \frac{2 \sin ^{4} 1 / 2 t}{\sin I^{\prime \prime}} .
$$

Das zweite Glied dieses Ausdrucks kann selbst bei polnahen, unter einem erheblichen Stundenwinkel im Meridianrohr zu beobachtenden Sternen nicht o". I ausmachen, so dass also das erste Glied die gesammte Reduction dar. stellt. In der ersten Formel kann das zweite Glied bei polnahen Sternen jedoch sehr wohl mehrere Bogensecunden betragen. Benutzt man daher bei Berechnung der Reduction nach der ersten Formel statt der unreducirten Declination die wahre, so fälscht man das Resultat um den vollen Betrag des zweiten Gliedes. 